\title{
Tax Revenue and Budget Implementation in Nigeria
}

\author{
Festus Oladipupo Olaoye, Akintayo Abiodun Akinola \\ Department of Accounting, Ekiti State University, Ado-Ekiti, Nigeria \\ Email: oladipupo.olaoye@eksu.edu.ng
}

How to cite this paper: Olaoye, F.O. and Akinola, A.A. (2019) Tax Revenue and Budget Implementation in Nigeria. American Journal of Industrial and Business Management, 9, 1219-1233.

https://doi.org/10.4236/ajibm.2019.95082

Received: March 24, 2019

Accepted: May 24, 2019

Published: May 27, 2019

Copyright (c) 2019 by author(s) and Scientific Research Publishing Inc. This work is licensed under the Creative Commons Attribution International License (CC BY 4.0).

http://creativecommons.org/licenses/by/4.0/

(c) (i) Open Access

\begin{abstract}
This study examined tax revenue and budget implementation in Nigeria. Secondary method of data collection was adopted for a period of 40 quarters from 2008Q1 to 2017Q4. The study made use of Fully Modified Least Square (FMOLS) and Error Correction Model (ECM) based on ARDL approach, after conducted pretest such as unit root test, and co-integration test. Result showed that tax revenue including petroleum profit tax and company income contributes positively and significantly to capital budget implementation in Nigeria, while custom and excise duties significantly and negative affect capital budget implementation in Nigeria; that custom \& excise duties as well as value added tax contributes significantly and positively to recurrent budget implementation in Nigeria, while tax revenue from petroleum profit tax significantly and negatively influences recurrent budget implementation in the country. Hence the study recommends that government should engage more of tax revenue generated from both petroleum profit tax and company income tax toward capital projects in the country, rather than recurrent expenditure and collection cost minimization strategy should be device by government through the federal inland revenue services and other tax regulatory bodies especially in terms of both customs \& excise duties and value added tax, so as to ensure that proceed from these sources can contribute largely to capital budget implementation.
\end{abstract}

\section{Keywords}

Tax Revenue, Budget, Budget Implementation, Actual Expenditure

\section{Introduction}

Tax revenue is one of the major sources of revenue for government both in developed and developing nations. In most developing countries focus has contin- 
ued to tilt in favour of domestic resources mobilization through taxes, in the quest to meet with the burgeoning government expenditure demand [1]. Tax revenue in most African countries have continued to swing upward in the past five (5) years following a sharp decline in government revenue from both the end of the so-called commodities super-cycle and the oil price crash of mid/late 2014 [1]. In recent time, tax revenue collected by Sub-Saharan African countries (Nigeria inclusive) is more than those in Middle East and North Africa [MENA] or South Asia and indeed, is catching up quickly with the East Asia and Pacific region. In clear term tax revenue is becoming more recognized and harnessed by developing nations of the world for ensuring effective and efficient expenditure execution for better budget implementation. In Nigeria revenue from non-oil taxes such as company income tax, valued added tax and custom and excise duties has been on the rise in recent years. As reported by [2], actual value added tax rose from 194.2 billion in the fourth quarter of 2014 to 245.4 billion naira in the fourth quarter of 2017. Rise in actual company income tax in the same period frame was from 245 billion to 543 billion naira while that of custom and excise duties stood between 136.28 billion to 151.68 billion naira. However despite the rise in tax revenue over time, the level of budget implementation has not been satisfactory. As relayed in the budget implementation reports for 2015, 2016 and 2017, actual total expenditure has always fallen short of the budget figure; for instance in 2015 actual expenditure stood at 4767 billion naira, as against 5067.90 billion naira budgeted; in 2016 actual stood at 4396.24 billion naira as against budget value of 6060.48 billion naira, while as at the third quarter of 2017 actual expenditure stood at 4145.53 billion naira, out of the 7441.18 billion naira budget for the year.

In Nigeria, previous studies on tax revenue focused largely on its impact of economic growth for instance; [3] analyzed impact of tax revenue on economic growth of Nigeria; [4] analyzed the impact of tax revenue on economic growth of Nigeria; [5] studied tax revenue and Nigerian economic growth. On the other hand studies on budget implementation focused largely problems and prospect of budget implementation and/or the impact of budget implementation on economic growth of Nigeria; for instance [6] assessed problem and prospect of budget and budgeting in the third tier of government; [7] studied budget preparation and implementation in Nigerian public sector; [8] examined budget implementation and economic growth of Nigeria. Observably, previous studies do not relate tax revenue with the level of budget implementation, in addition to the fact most of the previous studies which made use of budgeted dataset both for tax revenue and government expenditure. Following the Fiscal Responsibility Act [FRA] of 2007, reports on actual tax revenue, government recurrent and capital expenditure were made available on quarterly basis for accountability and transparency of budget implementation process. However none of the previous studies employed such actual dataset in the discourse of tax revenue and budget implementation. 
To objectively track the impact of tax revenue on budget implementation, this study focused on the actual tax revenue and actual government expenditure on quarterly basis over the periods following the Fiscal responsibility Act. Hence this study objectively analyzed the interconnection between tax revenue and budget implementation by applying advance multivariate time series analysis to actual tax revenue and expenditure implementation on quarterly basis, with specific focus on the impact of actual tax revenues on actual recurrent expenditure of Nigeria and capital expenditure of Nigeria. This article is organized as follows. In Section 2 related literatures were reviewed covering key concepts, theory and empirical literature. In Section 3 details research method employed in the study, Section 4 covers data analysis and interpretation and Section 5 presents conclusion and recommendations.

\section{Literature Review}

\subsection{Tax Revenue}

Taxation is an important source of revenue for governments all over the world. According to [9], taxation is a compulsory levy imposed by the government through its agencies on the income, consumption and capital of its subjects. These levies are made on personal income, such as salaries, business profits, interests, dividends, discounts and royalties. It is also levied against company's profits petroleum profits, capital gains and capital transfer. Tax is a compulsory levy imposed on a subject or upon his property by the government to provide security, social amenities and create conditions for the economic wellbeing of the society [10]. [11] stated that taxation is a concept and the science of imposing tax on citizens. He further stated that, tax is a compulsory levy which is required to be paid by every citizen. It is considered as a civic duty. The imposition of taxation is expected to yield income which should be utilized in the provision of amenities, both social and security and creates conditions for the economic wellbeing of the society. Tax revenue can either be oil-related or non-oil related. Example of non-oil tax revenue is company income tax, value added tax, custom and excise duties, capital gain tax, while non-oil tax revenue includes petroleum profit tax and gas tax.

\subsection{Budget Implementation}

Budget implementation entails ensuring that both revenue projections and expenditure framework contained in the approved budget document are achieved within the fiscal years. According to [11] budget implementation at any level of government reflects a large extent of the measure of accountability and transparency in the systems. As observed by [12], budgeting process has gone beyond an annual ritual; it is today known to be very strategic in nature and all-encompassing as it is through it the government scarce resources are allocated to programmes and services for governmental operations. This makes budget process a powerful tool for participatory governance. Budgeting is a serious business that sets the 
tone for development in a polity, usually for a 12-month period, and a government without a financial plan is walking blindfolded [13]. Budget is an instrument of fiscal policy, which reflects government control over size and relationship between government receipts (revenue) and expenditures, usually designed to cover a specified period of time. Budget in modern times, therefore means the document which contains estimates of revenue and expenditure of a country usually for one year [13]. Budget is an instrument stipulating policies and programmes aimed at realizing the development objectives of a government [7]

\subsection{Theoretical Review}

\section{Adolph Wagner Theory}

In the 19th century a German economist, Wagner (1883), formulated a "Law of Expanding State Expenditures", and the main point of his work is the growing importance of government activity and expenditure as an inevitable feature of a "progressive" state. A modern formulation of Wagner's "law" as proposed by Bird (1971) might run as follows: as per capita income rises in industrializing nations, their public sectors will grow in relative importance. Wagner included in the work three reasons why the development of public spending will take place. Firstly, an expansion of state expenditures would come about with respect to the administrative and protective functions of the state. His explanation based on substitution of public for private activity. After some years, new factors have been added, such as the increase in population density and urbanization, consequently that leads to increased state (public) expenditures and economic regulation. Wagner claimed that the inevitable changes in technology and investment required in many activities would generate an increasing number of private monopolies. This effect would have to be offset, or the monopolies taken over, by the state interests of economic efficiency (the main example was the railroad).Wagner in his original study also recognised that the state expansion has some limits, which reflect that budget implementation could be limited in the absence of adequate funds.

\subsection{Empirical Review}

Study conducted by [14] evaluated the problems and prospects of budgeting and budget in implementation in local government system in Nigeria. A discursive methodology was embraced to establish how beneficial L.G had been of great importance to both rural and urban areas respectively in terms of social amenities such roads, health clinics, water, education etc. The study revealed that the aforementioned activities of local government though remarkable, generated an increased national poverty rate specifically amongst rural area residents due to poor budgeting and implementation and lack of federal and state government aid. Thus, the study suggested that the expenditures by L.G. A should be monitored by the national budget board for more diversified performance and money will be spent according to deliberated proposition. [7] examined budget prepara- 
tion and implementation in the Nigerian public sector. Both descriptive and discursive techniques were adopted to give an in-depth explanation on budgeting and budget implementation in the country. Results bore that the continuous incorporation or application of variables like concept of value money audit, process and cost audit in conjunction with concrete public procurement theory birth the solid legal, organizational and professional structure which paved way for the enormous and palpable budgeting and budgeting implementation related conducted by [8] examined budget implementation and economic growth in Nigeria. The study employed ordinary Least Square (OLS) regression test using time series data from 1993-2010. Findings revealed that budget implementation had positive influence on national economic growth and that there is existence of positive correlation between gross domestic product (GDP) and public capital expenditure, public recurrent expenditure (PRE), public total expenditure (PEX), external debt (EXD). Also on the discourse of budgeting and its implementation study conducted by [15] examined factors responsible for budget failure in Nigeria. The study adopted econometric model of Analysis of Variance (ANOVA) regression test and time series data from 2010 to 2015. The results indicated that budget served as ritual or yearly which though good in content but without remarkable output in the public sector; that budgeting had strong correlation with the national GDP; and that, budgeting strongly correlated to poverty index (PI). It is recommended that more capital expenditure should be put in the budget plan so as to spring up the value of social development. Recently [16] examined budget implementation and governance in Nigeria. The study utilized descriptive and discursive techniques in the quest to identify whether or not budgeting and budgeting implementation facilitated good governance in the country. Result bore that the egregious budget implementation as a result of unrealistic desire on target beneficiaries was significantly affected by poor governance. In the same vein study conducted by [6] examined budget and budgeting in the third tier of government: problems and prospects. The study adopted discursive analysis, which unveiled the national controversies on whether or not provision of basic services by local government was beneficiary to the wellness of citizenry due to nonstop poverty rate. It is argued that the influence of budget on the socio-economic development of a country depended solely on effective budget pattern and implementation. Therefore, federal government should draw a budgeting skeleton which will monitor the budgeting process of all local government areas. [17] evaluated Nigerian budget implementation and control reforms: tool for macroeconomic growth. Primary data; from Accountants and Economists in the federal civil service, and secondary data; from journals and other scholars publications, were used to show the effect of budget on resource management, overhead costs, productivity, personnel and efficiency. Through findings, it is identified that poor project conceptualization and planning by ministries, departments and firms engendered the retardation in management of resources. Recommendation suggested the need for tighter 
usage of well implemented budget in order to vitalize macroeconomic growth in federal, state and local government levels.

Recent empirical investigation on the subject matter of tax revenue such as the work of [4] examined the connection between tax revenue and Nigeria economy. The study employed both descriptive survey design and simple random sampling technique in which 75 ( $75 \%$ response rate) out of the 100 copies of questionnaires distributed were perfectly completed by the FBIR employees, Lagos, Nigeria. The study discovered that tax revenue significantly influenced Federal Government Budget implementation, government revenue has significant impact on tax administration, incompetency on the part of the tax board staffs significantly influenced government revenue generation and that tax evasion affected significantly national government revenue. [5] investigated tax revenue and Nigerian economic growth. Data were obtained from Central Bank of Nigeria (CBN) Statistical Bulletin and National Bureau of Statistics (NBS), and were analyzed with the use of Statistical Package for Social Science (SPSS) version 23. Findings revealed that oil and non-oil tax revenue correlated strongly and positively with Real Gross Domestic Product (RGDP). And, there was a significant difference between the impacts of oil and non-oil tax revenue on RGDP. Based on the results, it is recommended that government should prioritize accountability and transparency on the coordination of revenue obtained from oil and non-oil taxation in the country under review. [3] investigated the impact of tax revenue on economic growth: evidence from Nigeria. Data were generated from the Central Bank Statistical Bulletin, desk survey method, and Ordinary Least Square of multiple regressions was employed to ascertain the correlation between dependent and independent variables. Result showed a significant correlation between oil profit tax and the economic growth, a significant correlation between non-oil revenue and economic growth meanwhile, no significant correlation between firm income tax and the economic growth of Nigeria. Notably, empirical investigations conducted in recent past do not capture in specific terms the role played by tax revenue in the discourse of budget implementation in Nigeria and also past studies on budget implementation at the national level could not assess the interrelationship between tax revenue and budget implementation level using actual tax revenue, government recurrent and capital expenditure.

\section{Research Method}

\section{Model Specification}

This study adapted the model used by [18] to analyze the nexus between government expenditure and tax revenue: The adapted model specified government expenditure as a function of aggregated tax revenue see Equation (i) below:

$$
G E_{t}=\alpha_{0}+\alpha_{1} T R_{t}+\mu_{i t}
$$

where $G E=$ Government Expenditure, $T R$ is Ta Revenue, and $u$ is the stochastic error term. 
This study modified the model by disaggregating tax revenue into sub-set including value added tax, company income tax, custom and excise duties and petroleum profit tax, while government expenditure was also disaggregated into capital and recurrent expenditure. The new version of the model used by [18] is presented in functional and linear forms below:

$$
\begin{gathered}
A C E=f(A V A T, A C I T, A C E D, A P P T) \\
A R E=f(A V A T, A C I T, A C E D, A P P T) \\
A C E_{t}=\alpha_{0}+\alpha_{1} A V A T_{t}+\alpha_{2} A C I T_{t}+\alpha_{3} A C E D_{t}+\alpha_{3} A P P T_{t}+\mu_{i t} \\
A R E_{t}=\alpha_{0}+\alpha_{1} A V A T_{t}+\alpha_{2} A C I T_{t}+\alpha_{3} A C E D_{t}+\alpha_{3} A P P T_{t}+\mu_{i t}
\end{gathered}
$$

Scope, Source(s) of Data and Techniques of Analysis

This study covered a period of 10 years spanning from 2008 to 2017 being an era characterized by preparation and dissemination of budget implementation report in accordance with section 30 and 50 of the Fiscal Responsibility Act [FRA], 2007, which is a reflection of government determination to ensure transparency and accountability in the management of public resource as well as effectiveness and efficiency in the management of national resources to achieve governmental objectives. This study made use of quarterly data sourced from the Office of the Accountant General of the Federation [OAGF] and Budget Office of the Federation $[\mathrm{BOF}]$ as contained in the annual budget implementation report for period understudied. This study employed Fully Modified Least Square (FMOLS) and Error Correction Model (ECM) based on ARDL approach, after conducted pretest such as unit root test, and co-integration test.

\section{Data Analysis and Result}

\section{Correlation Analysis}

Correlation result presented in Table 1 showed that actual value added tax and actual customs and excise duties move predominantly in opposite direction with actual capital expenditure of Nigeria for the period understudied. Observably statistics reported for pairs of $A C E$ and $A V A T, A C E$ and $A C E D$ is weak at -0.132479 and -0.171952 respectively. On the other hand the result showed that actual capital expenditure moves in the same direction with both company income tax and actual petroleum tax, with weak correlation statistics of 0.108264 and 0.345751 for $A C E$ and CIT, $A C E$ and $A P P T$ respectively. Result showed that actual recurrent expenditure also stood at predominantly with all tax revenue variables identified in the study except actual petroleum profit tax. Specifically reported statistics stood at $0.837884,0.002591,0.837507$, for $A R E$ and $A V A T$, $A R E$ and $A C I T, A R E$ and $A C E D, A R E$ and $A P P T$ respectively, while the correlation between actual recurrent expenditure and petroleum profit tax is negative and weak at -0.111246 .

Unit root test result presented in Table 2 revealed that variables used in the study are of mix order of integration. While actual capital expenditure and actual company income tax are integrated of order zero i.e. I (0), actual recurrent 
expenditure, actual value added tax, actual custom and excise duties, and actual petroleum profit are integrated of order i.e. I (1). Result reflect that both actual capital expenditure and are stationary at level, which connote that they do not retain innovative shock passed on time, at any point in time, which other variables are said to be stationary at first difference, which by implication showed that these variables retain innovative shock passed on them only for a short period of time. Following the confirmation of the variables being integrated mix order one I (1) or order zero I ( 0 ), it stands that there is no equilibrium relationship among the variables in the short run with the presence of unit root in about four of the identified variables. Hence the study conducted an ARDL co-integration bound test.

Table 3 revealed that that there is enough evidence to reject the null hypothesis that there is no co-integration amidst the variables, for both model 1 and model 2, which reflect that despite the non-stationarity of some of the variables at level, which engender disequilibrium interrelation in the short run, linear combination of these variables will yield a stationary series, meaning that the short run inconsistency in the models of the study are easily corrected over time such that there is existence of equilibrium relationship on the long run. The validation for co-integration stemmed from the fact that the estimated f-statistics is beyond the upper bound critical value for both models. Hence the study established that there is long run equilibrium interrelationship between tax revenue variables and budget implementation measured in terms of both actual capital expenditure and actual recurrent expenditure.

Estimation of the long run interrelationship between actual tax revenues and actual expenditure was done with the use of Fully Modified Least Square (FMOLS) estimator for the two models specified in the study. The use of Fully Modified least Square estimator stemmed from the fact that estimation of co-integrated series with Ordinary least square exhibit estimates with asymptotic distribution that is generally non-Gaussian, as well as asymptotic bias. Hence this study adopted the fully modified OLS to estimates the single co-integrating vector proposed by Phillips and Hansen (1990) which employs a semi-parametric correction to eliminate the problems caused by the long run correlation between the co-integrating equation and stochastic regressors innovations. The resulting Fully Modified OLS (FMOLS) estimator is asymptotically unbiased and has fully efficient mixture normal asymptotic, allowing for standard Wald tests using asymptotic Chi-square statistical inference.

Long run estimation presented in Table 4 revealed that actual value added tax exert insignificant positive impact on actual capital expenditure, with reported coefficient estimate of 0.338137 ( $\mathrm{p}=0.6203>0.05$ ), actual company income tax exert significant positive on actual capital expenditure, with coefficient estimate of 0.588920 ( $\mathrm{p}=0.0000<0.05)$, long run impact of custom and excise duties on actual capital expenditure is negative and significant, with coefficient estimate of $-3.000603(\mathrm{p}=0.0077<0.05)$, while long run impact of petroleum profit tax on 
actual capital expenditure is positive and significant, with coefficient estimate of 0.195577 ( $\mathrm{p}=0.0004<0.05$ ). Reported R-square stood at 0.760666 , which reflect that on the long run about $76 \%$ of the systematic variation in actual capital expenditure can be jointly explained by the tax revenues identified in the study.

Estimation result presented in Table 5 showed that tax revenues included in the model exert positive impact on actual recurrent expenditure except actual petroleum profit tax. Specific coefficient estimate reported in Table 5 stood at $1.779831(\mathrm{p}=0.0286<0.05), 0.237674(\mathrm{p}=0.0911>0.05), 4.110139(\mathrm{p}=0.0019$ $<0.05),-0.159701(\mathrm{p}=0.0084<0.05)$ for actual value added tax, actual company income tax, actual custom and excise duties, and actual petroleum profit tax respectively. Result showed the long run impact of all the tax revenue on actual recurrent expenditure is statistically significant at 0.05 significance level, except for company income tax. Reported R-square stood at 0.753053 , which reflect that on the long run about $75 \%$ of the systematic variation in actual recurrent expenditure can be jointly explained by the tax revenues such as value added tax, company income tax, custom and excise duties and petroleum profit tax.

Table 1. Correlation matrix.

\begin{tabular}{ccccccc}
\hline \multicolumn{1}{c}{ ACE } & ARE & AVAT & ACIT & ACED & APPT \\
\hline ACE & 1.0000 & & & & & \\
ARE & -0.084819 & 1.0000 & & & & \\
AVAT & -0.132479 & 0.837884 & 1.0000 & & & \\
ACIT & 0.108264 & 0.002591 & 0.102767 & 1.0000 & & \\
ACED & -0.171952 & 0.837507 & 0.909468 & -0.045018 & 1.0000 & \\
APPT & 0.345751 & -0.111246 & -3.556955 & 0.178128 & 0.0735844 & 1.0000 \\
\hline
\end{tabular}

Sources: Author's computation (2019).

Table 2. Unit root test result.

\begin{tabular}{cccccccc}
\hline \multicolumn{1}{c}{ At Level } & \multicolumn{5}{c}{ At First Difference } \\
\hline Variables & $\begin{array}{c}\text { ADF } \\
\text { statistics }\end{array}$ & $\begin{array}{c}1 \% \\
\text { critical } \\
\text { value }\end{array}$ & $\begin{array}{c}5 \% \\
\text { critical } \\
\text { value }\end{array}$ & $\begin{array}{c}\text { ADF } \\
\text { statistics }\end{array}$ & $\begin{array}{c}\mathbf{1} \% \\
\text { critical } \\
\text { value }\end{array}$ & $\begin{array}{c}\mathbf{5} \% \\
\text { critical } \\
\text { value }\end{array}$ & $\begin{array}{c}\text { Order } \\
\text { of } \\
\text { integration }\end{array}$ \\
\hline$A C E$ & $-4.299301^{*}$ & -3.610453 & -2.938987 & --- & --- & --- & $\mathrm{I}(0)$ \\
$A R E$ & -0.556498 & -3.615588 & -2.941145 & $-14.92359^{*}$ & -3.615588 & -2.941145 & $\mathrm{I}(1)$ \\
$A V A T$ & -0.844933 & -3.610453 & -2.938987 & $-7.338665^{*}$ & -3.615588 & -2.941145 & $\mathrm{I}(1)$ \\
$A C I T$ & $-6.171221^{*}$ & -3.610453 & -2.938987 & --- & --- & --- & $\mathrm{I}(0)$ \\
$A C E D$ & -1.146373 & -3.610453 & -2.938987 & $-6.912892^{*}$ & -3.615588 & -2.941145 & $\mathrm{I}(1)$ \\
$A P P T$ & -1.238224 & -3.615588 & -2.941145 & $-8.759685^{*}$ & -3.615588 & -2.941145 & $\mathrm{I}(1)$ \\
\hline
\end{tabular}

Note: ${ }^{*}$ connote significance at $1 \%$ level of significance. Source: Author's computation (2019). 
Table 3. ARDL co-integration bound test.

\begin{tabular}{cccc}
\hline Models & F-Statistic & Lower Bound Critical Value & Upper Bound Critical Value \\
\hline Model 1 & 13.06269 & 2.26 & 3.48 \\
Model 2 & 44.02475 & 2.26 & 3.48 \\
\hline
\end{tabular}

Note: Asymptotic critical values are obtained from table $\mathrm{F}$ in appendix C, Case III: intercept and trend for $\mathrm{k}$ $=5($ Pesaran and Pesaran, 1997, p. 478) at 5\% significant level.

Table 4. Co-integration regression result (Model 1). Series: ACE AVATCIT CED APPT.

\begin{tabular}{ccccc}
\hline Variables & Coefficient & Std. Error & t-Statistics & Probability \\
\hline C & 214.9722 & 56.34648 & 3.815185 & 0.0005 \\
$A V A T$ & 0.338137 & 0.676375 & 0.499926 & 0.6203 \\
$A C I T$ & $0.588920^{* *}$ & 0.118701 & 4.961370 & 0.0000 \\
$A C E D$ & $-3.000603^{* *}$ & 1.059503 & -2.832086 & 0.0077 \\
$A P P T$ & $0.195577^{* *}$ & 0.049598 & 3.943251 & 0.0004 \\
\hline
\end{tabular}

R-square $=0.760666$, Adjusted R-square $=0.745450,{ }^{* *}$ connote significance at $5 \%$ level of significance, Source: Author's computation (2019).

Table 5. Co-integration regression result (Model 2). Series: ARE AVATCIT CED APPT.

\begin{tabular}{ccccc}
\hline Variables & Coefficient & Std. Error & t-Statistics & Probability \\
\hline C & 61.03251 & 64.87871 & 0.940717 & 0.3535 \\
$A V A T$ & $1.779831^{* *}$ & 0.778794 & 2.285367 & 0.0286 \\
$A C I T$ & 0.237674 & 0.136675 & 1.738966 & 0.0911 \\
$A C E D$ & $4.110139^{* *}$ & 1.219937 & 3.369140 & 0.0019 \\
$A P P T$ & $-0.159701^{* *}$ & 0.057108 & -2.796449 & 0.0084 \\
\hline
\end{tabular}

R-square $=0.753053$, Adjusted R-square $=0.724001,{ }^{\star *}$ connote significance at $5 \%$ level of significance, Source: Author's computation (2019).

\subsection{Error Correction Model (ECM)}

Error correction model estimation reflect the Short run impact of tax revenue on budget implementation measured in terms of actual capital expenditure and actual recurrent expenditure and track the mechanism of adjustment of the short run disequilibrium relationship and how the short run inconsistencies was corrected over time to establish the long run equilibrium relationship reflected in co-integration regression estimation presented in Table 4 and Table 5 for model 1 and 2. This study employed an ARDL estimation selected based on Akaike information criterion. Parsimonious model of order ARDL $(1,0,0,2,1)$ was selected for model 1 and ARDL $(1,0,0,0,0)$ for model 2 as presented in Table 6 and Table 7.

Parsimonious result presented in Table 6 revealed that on the short run actual value added tax exert insignificant negative impact on actual capital expenditure with coefficient estimate of -2.131155 ( $\mathrm{p}=0.1614>0.05$ ), actual company income tax exert insignificant negative impact on actual capital expenditure, with 
coefficient estimate of -0.002946 ( $\mathrm{p}=0.4404>0.05$ ), custom and excise duties exert significant negative impact on actual capital expenditure, with coefficient estimate of -4.130201 ( $\mathrm{p}=0.0235<0.05$ ), while petroleum profit tax exert significant positive impact on actual capital expenditure, with reported coefficient estimate of 0.448026 ( $p=0.0020<0.05$ ). Coefficient of the lagged error correction term ECT $(-1)$ reported in Table 6 revealed that $100 \%$ of the short run inconsistencies is significantly corrected and incorporated into the long run dynamic quarterly, thus reflecting the adjustment power of the model estimated to ascertain the effect of tax revenue on actual capital expenditure. R-square statistics of 0.667141 reported in Table 6 revealed that about $67 \%$ of the systematic variation in actual capital expenditure can be explained by tax revenue including value added tax, company income tax, custom and excise duties and petroleum profit tax.

Post estimation test presented in Table 7 reflect that the parsimonious ECM model presented in Table 6 is robust enough to capture the impact of tax revenue on budget implementation measured in terms of actual capital expenditure, as test results validate the linear specification, normality of error term, absence of serial correlation and homoscedastic variance of the error term, given reported probability values for each test which reflects acceptance of corresponding null hypothesis of appropriate linear specific, normality of error term, absence of serial autocorrelation and equal variance of the error term.

Estimation result presented in Table 8 revealed that on the short run, actual value added tax exert insignificant positive impact on actual recurrent expenditure, with coefficient estimate of 0.124942 ( $\mathrm{p}=0.9405>0.05)$, company income tax exert insignificant positive impact on actual recurrent expenditure 0.001627 $(p=0.7113>0.05)$, custom \& excise duties exert significant positive impact on actual recurrent expenditure $5.181230(\mathrm{p}=0.0074<0.05)$. Result also showed that on the short run petroleum profit tax exert insignificant positive impact on actual recurrent expenditure $0.121280(\mathrm{p}=0.0058<0.05)$. Estimated coefficient for error correction term lagged by a period stood at -0.732312 ( $\mathrm{p}=0.0058<$ 0.05 ) which connote that about $73 \%$ of the systematic variation in the short run disequilibrium was corrected every quarter and incorporated into the long run dynamics. Reported R-square stood at 0.667141 which implies that about $67 \%$ of the systematic variation in actual recurrent expenditure can jointly be explained by the independent variables of the estimated model.

Test result presented in Table 9 revealed that parsimonious ECM model presented in Table 8 is robust enough to capture the impact of tax revenue on budget implementation measured in terms of actual recurrent expenditure, as result validates the linear specification of the model, normality of error term, absence of serial correlation and equal variance of the error term, given reported probability values for each test which reflect acceptance of corresponding null hypothesis of appropriate linear specific, normality of error term, absence of serial autocorrelation and equal variance of the error term. 
Table 6. Parsimonious ECM estimation (Model 1). Series: ACE VAT PPT CIT CED TOE.

\begin{tabular}{ccccc}
\hline Variables & Coefficient & Std. Error & t-Statistics & Probability \\
\hline $\mathrm{C}$ & 26.64805 & 18.17642 & 1.466077 & 0.1542 \\
$\mathrm{D}(A C E(-1))$ & 0.304626 & 0.177354 & 1.717619 & 0.0973 \\
$\mathrm{D}(A V A T)$ & -2.131155 & 1.480105 & -1.439867 & 0.1614 \\
$\mathrm{D}(A C I T)$ & -0.002946 & 0.003762 & -0.783119 & 0.4404 \\
$\mathrm{D}(A C E D)$ & $-4.130201^{* *}$ & 1.720120 & -2.401111 & 0.0235 \\
$\mathrm{D}(A C E D(-1))$ & -0.101924 & 1.621682 & -0.062851 & 0.9503 \\
$\mathrm{D}(A C E D(-2))$ & $-4.538447^{* *}$ & 1.602402 & -2.832276 & 0.0086 \\
$\mathrm{D}(A P P T)$ & $0.448026^{* *}$ & 0.130657 & 3.429031 & 0.0020 \\
$\mathrm{D}(A P P T(-1))$ & 0.182205 & 0.137398 & 1.326106 & 0.1959 \\
$\mathrm{ECT}(-1)$ & $-1.063001^{* *}$ & 0.236747 & -4.490031 & 0.0001 \\
\hline
\end{tabular}

R-square $=0.667141$, Adjusted R-square $=0.556188$, F-statistics $=6.012820$, Prob(F-stat $)=0.000129$ Durbin-Watson $=2.084558,{ }^{* *}$ connote significance at $5 \%$ level of significance, Source: Author's computation (2019).

Table 7. Post estimation test (Model 1).

\begin{tabular}{ccc}
\hline & Linearity Test & \\
\hline Statistics & Values & Probability \\
F-statistic & 0.210746 & 0.6500 \\
& Normality Test & \\
Statistics & Values & Probability \\
Jarque-Bera Stat & 1.493891 & 0.473812 \\
& Serial Correlation LM Test & \\
Statistics & Values & Probability \\
F-statistic & 0.206152 & 0.8151 \\
& Heteroscedasticity Test & Probability \\
Statistics & Values & 0.0919 \\
F-statistic & 1.919917 & \\
\hline
\end{tabular}

Source: Author's computation (2019).

Table 8. Parsimonious ECM estimation (Model 2). Series: ARE AVATCIT CED APPT.

\begin{tabular}{ccccc}
\hline Variables & Coefficient & Std. Error & t-statistics & Probability \\
\hline $\mathrm{C}$ & 14.17775 & 19.69300 & 0.719938 & 0.4770 \\
$\mathrm{D}($ ARE $(-1))$ & $-0.379471^{* *}$ & 0.160117 & -2.369958 & 0.0242 \\
$\mathrm{D}($ AVIT $)$ & 0.124942 & 1.661718 & 0.075188 & 0.9405 \\
$\mathrm{D}($ ACIT $)$ & 0.001627 & 0.004355 & 0.373592 & 0.7113 \\
$\mathrm{D}($ ACED $)$ & $5.181230^{* *}$ & 1.809003 & 2.864136 & 0.0074 \\
$\mathrm{D}($ APPT $)$ & 0.121280 & 0.142025 & 0.853932 & 0.3997 \\
$\mathrm{ECT}(-1)$ & $-0.732312^{* *}$ & 0.247181 & -2.962653 & 0.0058 \\
\hline
\end{tabular}

R-square $=0.667141$, Adjusted R-square $=0.556188$, F-statistics $=6.012820$, Prob(F-stat $)=0.000129$ Durbin-Watson $=2.084558,{ }^{* *}$ connote significance at $5 \%$ level of significance, Source: Author's computation (2019). 
Table 9. Post estimation test (Model 2).

\begin{tabular}{ccc}
\hline & Linearity Test & \\
\hline Statistics & Values & Probability \\
T-statistic & 2.115422 & 0.1562 \\
& Normality Test & \\
Statistics & Values & Probability \\
Jarque-Bera Stat & 1.795126 & 0.652335 \\
& Serial Correlation LM Test & \\
Statistics & Values & Probability \\
F-statistic & 0.283559 & 0.7552 \\
& Heteroscedasticity Test & \\
Statistics & Values & Probability \\
F-statistic & 0.903481 & 0.5050 \\
\hline
\end{tabular}

Source: Author's computation (2019).

\subsection{Discussion}

Estimation results established that value added tax, company income tax, as well as custom \& excise duties exert negative impact on actual capital expenditure on the short run, with only the impact of custom and excise duties being significant at 0.05 significant threshold. On the other hand petroleum profit tax exerts significant positive impact on actual capital expenditure on the short run. On the long run value added tax, company income tax and petroleum profit tax exert positive impact on actual capital expenditure, with the impact of both company income tax and petroleum profit tax being significant, while on the other hand custom \& excise duties exert significant negative impact on actual capital expenditure on the long run.

All tax revenue exert positive impact on actual recurrent expenditure on the short run, with only the impact of custom and excise duties being significant at 0.05 level of significance. On the long run value added tax, company income tax and custom \& excise duties exert positive impact on actual recurrent expenditure, with the impact of both value added tax and customs \& excise duties being significant a 0.05 significance threshold. On the other hand petroleum profit tax exert significant negative impact on actual recurrent expenditure on the long run. Fundamentally result showed that custom and excise duties has significant negative impact on capital budget implementation in Nigeria, both on the short run and on the long run, while petroleum profit tax has significant positive impact of capital budget implementation both on the short run and on the long run, while the impact of company income tax on budget implementation is only significant on the long run. It was also established from the results that custom and excise duties has significant positive impact on recurrent budget implementation both on the short run and on the long run, and that the impact of value 
added tax on recurrent expenditure implementation is only significant on the long run, while on the other hand petroleum profit tax has significant negative impact on recurrent expenditure implementation only on the long run.

\section{Conclusion and Recommendation}

This study established that tax revenue including petroleum profit tax and company income contribute positively and significantly to capital budget implementation in Nigeria, while custom and excise duties significantly and negative affect capital budget implementation in Nigeria. Secondly, the study established that custom \& excise duties as well as value added tax contributes significantly and positively to recurrent budget implementation in Nigeria, while tax revenue from petroleum profit tax significantly and negatively influences recurrent budget implementation in the country. Hence the study recommends that government should engage more of tax revenue generated from both petroleum profit tax and company income tax toward capital projects in the country, rather than recurrent expenditure and collection cost minimization strategy should be device by government through the federal inland revenue services and other tax regulatory bodies especially in terms of both customs \& excise duties and value added tax, so as to ensure that proceed from these sources can contribute largely to capital budget implementation.

\section{Conflicts of Interest}

The authors declare no conflicts of interest regarding the publication of this paper.

\section{References}

[1] McNabb, K. (2017) Updated Government Revenue Dataset Provides New Insights into Developing Country Tax Collection Trends. https://www.ictd.ac/blog/updated-grd

[2] Budget Office of the Federation (2017) Budget Implementation Report. http://budgetoffice.gov.ng/index.php/quarterly-budget-implementation-reports/201 4-budget-implementation-reports?layout=default

[3] Ojong, C.M., Ogar, A. and Arikpo, O.F. (2016) The Impact of Tax Revenue on Economic Growth: Evidence from Nigeria. IOSR Journal of Economic and Finance, 7, 32-38.

[4] Abata, M.A. (2014) The Impact of Tax Revenue on Nigerian Economy (Case of Federal Board of Inland Revenue). Journal of Policy and Development Studies, 9, 109-121. https://doi.org/10.12816/0011186

[5] Ayeni, A.P., Ibrahim, J. and Adeyemi, A.O. (2017) Tax Revenue and Nigerian Economic Growth. European Journal of Accounting, Auditing and Finance Research, 5, 75-85.

[6] Igbara, N., Tordee, B., Nwadike, G. and Abuba, S. (2016) Budget and Budgeting in the Third Tier of Government: Problems and Prospects. Equatorial Journal of Finance and Management Sciences, 1, 1-9.

[7] Obara, C. (2013) Budget Preparation and Implementation in the Nigerian Public 
Sector. Research Journal of Finance and Accounting, 4, 50-54.

[8] Oke, M.O. (2013) Budget Implementation and Economic Growth in Nigeria. Developing Country Studies, 3, 1-7.

[9] Aguolu, O. (2004) Taxation and Tax Management in Nigeria. 3rd Edition, Meridan Associates, Enugu.

[10] Appah, E. (2004) Principles and Practice of Nigerian Taxation. Ezevin Mint. Printers, Port-Harcourt.

[11] Ojo, O. (2009) Impact of Microfinance on Entrepreneurial Development: The Case of Nigeria. The International Conference on Economics and Administration, Bucharest, 14-15 November 2009, 536-545.

[12] Adesopo, A. (2011) Re-Examining the Failing Inter-Governmental Fiscal Relations and Sustenance of Nigerian Federation: An Empirical Study. Asian Social Science, 7, 107-121. https://doi.org/10.5539/ass.v7n10p107

[13] Oniore, J.O. (2014) Budget Implementation and Economic Development in Delta State-Nigeria, 1991-2010. International Journal of Academic Research in Business and Social Sciences, 4, 333-344. https://doi.org/10.6007/IJARBSS/v4-i3/712

[14] Ugoh, S.C. and Ukpere, W.I. (2009) Problems and Prospects of Budgeting and Budget Implementation in Local Government System in Nigeria. African Journal of Business Management, 3, 836-846.

[15] Adekunle, S.B. (2014) Assessment of Factors Responsible for Budget Failure in Nigeria. Journal of Economic and Finance, 1, 1-15.

[16] Ianna, J.G. (2016) Budget Implementation and Governance in Nigeria. 1-8.

[17] Onyiah, I.A., Ezeamama, N.C., Ugwu, J.N. and Mgbodile, C.C. (2016) Nigerian Budget Implementation and Control Reforms: Tool for Macroeconomic Growth. British Journal of Economics, Management \& Trade, 11, 1-13. https://doi.org/10.9734/BJEMT/2016/19556

[18] Zinaz, A. and Samina, K. (2009) Government Expenditure and Tax Revenue, Causality and Co-Integration: The Experience of Pakistan (1972-2007). The Pakistan Development Review, 48, 951-959. https://doi.org/10.30541/v48i4IIpp.951-959 